\title{
De financiering van de welvaartsstaat - een dogmenhistorische beschouwing
}

Citation for published version (APA):

Backhaus, J. G. (1989). De financiering van de welvaartsstaat - een dogmenhistorische beschouwing. Maastricht University. https://doi.org/10.26481/spe.19891110jgb

Document status and date:

Published: 10/11/1989

DOI:

10.26481/spe.19891110jgb

Document Version:

Publisher's PDF, also known as Version of record

\section{Please check the document version of this publication:}

- A submitted manuscript is the version of the article upon submission and before peer-review. There can be important differences between the submitted version and the official published version of record.

People interested in the research are advised to contact the author for the final version of the publication, or visit the DOI to the publisher's website.

- The final author version and the galley proof are versions of the publication after peer review.

- The final published version features the final layout of the paper including the volume, issue and page numbers.

Link to publication

\footnotetext{
General rights rights.

- You may freely distribute the URL identifying the publication in the public portal. please follow below link for the End User Agreement:

www.umlib.nl/taverne-license

Take down policy

If you believe that this document breaches copyright please contact us at:

repository@maastrichtuniversity.nl

providing details and we will investigate your claim.
}

Copyright and moral rights for the publications made accessible in the public portal are retained by the authors and/or other copyright owners and it is a condition of accessing publications that users recognise and abide by the legal requirements associated with these

- Users may download and print one copy of any publication from the public portal for the purpose of private study or research.

- You may not further distribute the material or use it for any profit-making activity or commercial gain

If the publication is distributed under the terms of Article $25 \mathrm{fa}$ of the Dutch Copyright Act, indicated by the "Taverne" license above, 
DE FINANCIERING YAN DE WEL VAARTSSTAAT

Een dogmenhistorische beschouwing

\section{REDE}

in verkorte vorm uitgesproken bij de anvaarding van het ambt van gewoon hoogleraar Economie van het Overheidsgedrag en de Publieke Sector

aan de Rijksuniversiteit Limburg

op vrijdag 10 november 1989

door

J.G. Backhaus 
Het eerste punt van vertirek voor onze beschouwngen is dus de Nederlandse welvartsstad. Het tweede ultgangspunt $11 \mathrm{gt}$ in de geschledenis van deze faculteft besloten. De oprichters ervan streefden er namellalk natr de verschillende ecomomische discipllites, met name de algemene economle en de bedrijtseconomie, in onderzoek en onderwljs naw op elkatr te betrekken met het doel economen op te leiden die ôf aan de universiteit of in de praktijk wel degelljk in stat zijn problemen op te 105 sein. Op deze taak worden $z 1 \mathrm{~J}$ an deze faculteft woorbereid door in groepsverband met elkar samenwerkend en wan elkar lerend yragen te ontdekken, 2 warop de antwoorden in de wetenschappelijke iltteratuur en in gegevensbestanden te vinden zijm.

Deze randwoorwardien bepalen de opbouw van mijn betoog. Als anker kles ik de eerste systematische aanduiding van mijn vak als de leer van de weivartsstat. ${ }^{3}$ Ik lat dan zien hoe dit begin tot een degelljke leer der openbare funanctën ontwlkkeld kon worden. De dogmenhistorische excursle gat verder langs de weg van twee bellangrijke innovatles op het gebled der overheldsfinancién, te weten de accignsen en de publteke financlerings- en beleggingsinstituten warop mijn mede-orator dieper is ingegaan. 4 Ik ga dus vooral van de praktijk uit die de geschfedenis van mijn vak heeft gevormd. Maar er zijn ook theoretische ontwikelingen in de algememe economie geweest die een diepe invloed op het rak hebben gehad. Wij kunnen mar op éên voorbeeld ingaan, namelijk de fystocraten die al duldelljk de kansen en perikelen lieten zien die zllch kunnen voordoen als men ermaar streeft een theoretisch model op de praktijk der overheldsfimanciën toe te passen. Tot slat ga $1 k$ op de vraag in welke van de verschillende tradities th de leer der openubare flnanciën dife wij hebben besproken bijzonder belangrljk zijn voor de beoefening van het vak in een moderne ultgegroeide wellvartsstaat.

2 Zle J.H.C. Moust, P.A.J. Bouhuljs, H.G. Schmidt, Probleengestuurd leren: Een wequljzer voor studentem. Groningen: Wolters-Noordhoff, 1989.

3 Zle ook A.M. Donner, Over de term "welvaartsstat". Ansterdam: N.V. Noord-Holl andische Jitgevers Maatschappi], 1957.

4 Zle Christian Wolff, Penstoenverzekering? Een financleel-economische beschouwling. Rede in werkorte worm uitgesproken big de danvaarding van het ambt van gewoon hoogleraar financieel Management en Flnamcle le Markten aan de Rijksuniversiteit Limburg op vrljdag 10 november 1989. 
De natuur rechtellike wie ontrent de velvartsstat

De theorie van de moderne welvaartsstaat met as doel een leer der operbare financien en wan het statasrecht vindt hatar oorsprong in het werk van Chrlstian Wolff (1679-1754). Wolff was sinds 1707 hoogleraar wiskunde, wijsbegeerte en physica aan de universiteit Halle, de eerste unfiversitelt die over een leerstoel in de economie beschikte. Hij slagide erin, voortbouwend op de fllosofle van Lelbniz (1646-1716). diens stringent wiskundig-demonstratieve methode naar de ethischpraktische toepassingen wit te breiden en op die manter een grondslag te leggen warop de moderne leer der openbare financlën kon worden opgebouwd. Hij begon op zijn karakterfstleke manter met een bewijs dat een wetenschappelljke leer van de overheld (haar fimanciën ingesloten) met tastbare praktische resultaten mogellik zou kunnen zljn. W1j kunnen dit bewijs hier overslaan; tenslotte levert deze plechtighela vandaag voldoende bewljs dat een leer der openbare financiën wel degelljk mogelfjk is en kennelijk bestaansrecht heeft werworwen. Van groter belang vandaag is de praktische doelstelling die wolff an de leer der staatswetenschappen toekent. Deze doelstelling is momenteel nog letterlijk terug te vinden in de takomschrijuing van bijwoorbeeld de Algemene Rekenkamer. Deze controleert het owerhefdsgedrag niet alleen op rechtmatigheld mar beoordeelt ook de doelmatigheld, dat wil zeggen de verhouding van matschappelijke kasten en baten ofwel de efficièntle.

De onderdelen van een beschouwing wan het handellen wan de staat Aangezien wij nu weten dat het handelen van de staat voor een wetenschappelijke bemadering vatbaar is kunnen wij er ook lets dieper op ingaan. Zodra men begint het handelen van de stat te onderzoeken doen zich gewoonlijk twee vragen voor. De ene betreft het recht, of men bevoegd is or lets tie doen en of men lets kan doen zonder dat de rechten van iemand anders in het geding komen: de tweede wraag betreft het nut, dat wll zeggen of het van voordeel is lets well dan niet te doen. 5

Het is misschien van belang er even bif stll te staan dat dezelfde

5 Christian Fretherr von Wolff, Wan einer Erwegung der Statsgeschäfte". In: Gesamlete klelme phliosophlsche schriftiten. Halle: Renger, $1740,6 / z, 372-373$. 
tweevoudge doelltelling nog altid in de noderne leer der openbare financiên leeft. Waast vraagstukken met betrekking tot de allocatieve efflclientie wordt er in de vallteratuur steeds verdergaande aandacht besteed aan de rechtwaardige verdeling van goederen en diensten ("equtty"). De rechtwardigheld wordt dan wel besproken zonder verder op de concrete rechtsorde in ge gan. Rechtvaardigheld wordt in plats van rechtnatigheld benadrukt. Zo orelgt zich een comflict woor te doen tussen de geldende wetgeving en notles van verdelingsrechtvaardigheid, die an de econonlsche theorle van de welvart ontleend zijin. oft conflict doet zlch praktisch woor zodra de resultaten van een publiekeconomische analyse op de praktigk toegepast morden.

Wolff gat regelrecht op att probleem in en wist op de onlosmakellike verbondeniheld van de ecomomische en de jurldische analyse bif polltielieconoms she beleldswraagstukken.

Daarom moetem diegenen an wie de zorg woor de zaken van de staat is opgedragen vooral over twee deugden beschikken, te weten de rechtvaardigheld en de prudentle. De rechtvaardigheld hebben $z i j$ nodig om nitets te vragen of aan te raden dat onrechtvaardig is: ziJ moeten een hekell aan de onrechtmatigheld koesteren. De verstandigheid is vereist, on te voorkomen, dat $21 J$ schade brengen war zid nut wlllen stichten. 6

De moderne rechtseconomle heeft haar succes aan het nalleven van deze fundamentele inzlchten te danken.

De noodzak het acadentsch onderwlys op eén $11 \mathrm{Jn}$ te brengen met praktische problemen, krijgt Wollf's alandacht niet minder. Hij voegt eraan toe dat de beschikbare handboeken vanult dit oogpunt wel geschikt $z 1 j n$ als de student mar leert het nuttige en het overbodige wan elkar te sche lden. 7

Wolff, 1740, biz, 373-374.

7 Het Mastrichtse onderwijsaysteen werd opgezet on deze twee gezlchtspunten te verwezenllyken. Het onderwils verloopt "probleengestuurd" en de studenten worden er nadirukkelffk op gewezen de voor een bepald probleem meest geschikte literatuur te zooken on te klezen in platis van mar enkele aanbevolen handboeken van begin tot het efind te bestuderen. 
Wij bestuderen de statswetenschappen met geen ander doel dan te laten zien wat woor de stat van nut is en welke kennis ent vaardigheden men moet verwerven om woor het doen van de zaken wan de staat geschlkt te zljn. Ik moet toegeven dat hetgeen aan de scholen als stadswetenschappen gedoceerd wordt van gering mut is voor diegenen de in de praktijk voor de state zaken doen. Toch beweer ik dat hen in de boeken van verschill lende auteurs veell han vinden dat voor een systematische leer van het staatsbeheer nututg 15. 8

Het gesprek tussen wetenschap en praktijk was kennelljk vroeger al moeilljk. Tot slot geeft Wolff ons nog het essentiele advies dat wij nast de theorie ook moeten leren hoe $20^{\prime}$ n theorle kan worden toegepast (310). Een theoretisch inzficht kan alleen zinvol worder toegepast. zegt Wolff, als de concrete onstandigheden ontrent de toepassing ook ultvoerig aandacht helben gekregen (Ibidem).

Tot zover Wolff over doel en methode van de staatswetenschap. En wat zegt hij over de inhoud? Wij vinden de beginselen van zijn statsleer als deel van zijn staatsrecht, dat zelf het laatste deel van zijn Ius Naturae uitmakt. Voor ons zijn in de uitgave van $1754^{9}$ vooral de zes hoofdstukken van deel II, afdelling III van belang. Het meest belangrijke is voor ons, dat als doel van de staat en het overheldsgedrag ultsluitend de algemene welvart gesteld wordt. Zyjn staatswetenschap is de wetenschap van de welvaartsstaat die wij nog vandaag in de economische staatstheorle terugvinden. 10

\$ 972 Wij begrijpen zonder meer dat de afzonderlljke hutshoudingen zich niet op voldoende wijze van alles kunnen voorzien wat voor de elementalre levensbehoefte het comfort en het gemak, kort gezegd voor de welvart nodig is. Vaak kan een hulshouding op zichzelf gesteld niet rustlg van hatr rechten genteten moch zeker zijn dat

8 Wolff, 1740, biz. 409.

9 Christian Fretherr von Wolff, Grundsätze des Natur - und völckerrechts. Halle: Renger, 1754, III, 2.1.

10 Zie bljwoorbeeld Whllam j. Baumol, Welfare Economics and the Theory of the State. London: Bell, 1967 (2). 
aan alle vorderingen op anderen voldam wordt. noch dat hat vefligheld gewarborgd is. Het is dus nodig dat wat afizonderlijke hutshoudingen niet kunnen berelken gemeenschappelijk te doen. Met dit als enlg doel worden staten gevormd.

Het $1 \mathrm{~s}$ dan wel van belang dat bys Wolff de kleinste economische eenheden, zoals vandaag in de theorle gebrulkeltjk, nfet de individuen zifn, maar in plaats datuan de gezinnen of huishoudingen warlin geproduceerd en geconsumeerd wordt. Her worden dus economische beslissingen genomen. Wat de gezmmen niet zelf voor hun elgen welvart kumnen verwezenlljken wordt een taak wary de overheld. Maar dat wll nlet zeggen dat de taken van de overheld onbeperkt zljn. Met het oog op de hedendadgse problemen warin de welwartsstat verkeert is het belangrijk en boelend om te zlen hoe nauwkeurig Wolff de beperkingen van de bevoegdheden van de overhela omischrifft. 11

580 Aangezfer de bevoegdheden van een stat voortwloelen uit zifn doel gaan de bevaegdheden van de overheld ook niet verder dan het regellen van die activiteften van de burgers die met de bevordering van de algemene welvaart onmiskenbair samenhangen. Daarutt volgt dat alleen met betreking tot deze actlvitexten de naturr11jke vrifhetd van de hulshoudingen mag worden beperkt. Voor het overige blijft de vrijheid onaangetast.

De bevoegdheden wan de averheld gaan niet verder dan de precies onschreven doelelnden van de welwartsstat. De overheld heeft geen zeggenschap zolang de gezinnen hun economische functies kunnen vervullen. De voornaamste taak van de overheld is dan ook ervoor te zorgen dat de hulishoudingen in staat gesteld worden in hun behoeften zelf te voorzien.

\$ 1021 on ervopr te zorgen dat an alle levensbehoeften wordt woldaan is het belangrifk dat werkgelegenheid en ambacht zovael mogelljk worden ultgebreld, dat zlj die kunnen werken nlet ledig mogen gaan en zifj die wlllen werken ook werk kunnen vinden en op de manter federeen door zljn elgen inzet en werk voor zlchzelf

11 Zie ook James M. Buchanan, The Limits of Liberty: Between Anarchy and Leviathan. Chicago: Universtty of Chlcago Press, 1975. 
verwerft, wat nodig is voor behoefte en genak. Dit houdt wenwel in dat lonen en prijzen zodanig moeten zijn dat noch schaarste noch armoede potreden. De owerheid moet met alle matregelen trachten duurtes te voorkomen en ondat de vraag mar hout groot en essentleel is, moet de overheid ervoor zorgen dat er woldoende hout beschlkbaar kont en verder de burgers over het meest efficiënte gebruik van het hout inlichten.

Het citat uit 1021 lat duidelijk zien dat Wolff al drie doeleinden wan het hedendiagse financlële beleld benadrukt, te weten het workgelegenheldsbeleid [dat diegenen die wlllen werken ook werk kumnen vinden], het stabiliteltsbeleld ten anzien van de munt [durtes voorkomen] en het milleubeleid ten aanzien van de schaarse hulporon hout, toen de meest belangrijke grondstof voor alle soorten van constructies (met name in de woningbouw en de scheepsbouw) en de belangrijkste brandstof. Hout werd in de achtiende eeuw uitermate schars nadat de Europese houtwoorraad door roofbouw was uitgeput.

Het sociale beleid is bij wolff weer op de gezinnen toegespitst en theeft tot doel de huishoudingen hun taakvervuling mogel ljk te maken. Alleen war de gezinnen tekort schleten moet de overheld ingrijpen en dan wordt inderdaad het hele arsenaal van de toen bekende welvartsinstytuties en -madregelen tot ontplooing gebracht: armen- en sociale zorg, weeshuizen, werkgelegenheldsprograma's en (hento) opleidingsprograma's voor werklozen en de vilje toegang tot door de overheid op te richten scholen voor kinderen van arme ouders.

51022 On aan hun elementaire levensbehoeften te woldoen is het ook belangrijk, on voor de armen en bedelaars te zorgen en aan hun te verstrekken wat zij nodig hebben. Men moet wel voarkomen dat de burgers te zeer met byjoragen voor de armem belast worden, zodis in het natuurrecht van de bljdragen voor de amen ulteengezet (8 488 e. $\left.v_{*}\right)$. Daaron moet men instellingen stichten war zid die werken kunnen mar er geen zin in hebben tot een beroep opgeleid worden. Men moet armenhulzen instellen war diegenen die door hun eigen werk nlet aan hun behoeften kumien voidoen. well worden voorzien vain hetgeen $z 1 j$ nodig hebben voor hum levensbehoeften, voorzover zly niet over famllle of vrienden beschlkken die voor hen kunnen zorgen. Verder zijn ziekenhutzen nodig woor arme 
zfeken, on hen te verplagen en tie laten genezen en ook scholen warin de kinderen van arme ouders zonder lesgeld te betalen ondwwijs kumen wolgen dat woor hun opletding en opveding nodig en fiutelg is.

Een dermate groots opgezet soclaal programma roept metaen de wraag op, hoe het met de financlering staat. Wolf neent de hele 11 lst van de toen bekende en gebriklifellke overhefdsinkonsten door en voegt er meteen en warschuwing aan toe. Met het innen van invoerrechten en belastingen en het opleggen van buttengewone verplichtingen moet de regering viterst terughoudend zijn, ondat belastingen en andere bultengewone verpllchtingen de warde van het belastingobject doen dalen in Invoefrechten de prifzen doen stijgen. Beide werken in het nadeel van de beschikbare inkomens van de gezlnnen. De acilinsen noemt. nifi: nog niet.

Samenvattend kunnen wij de conclusle trekken, dat Wolff al de staatswetenschap als leer van de welvartsstat systematisch opbouwt, deze als een op de praktijk gertchte wetenschap opvat en ztch tot aanwilsbare personen richt die in het kader van een aanwijsbare rechtsorde op basis van 21 In wetenschappel $1 \mathrm{jk}$ advies besllssingen kunnen nemen.

\section{De kameralisten}

De kameralisten zijn dan de eersten, die op een systematische manier de gehele leer der openbare financiën ontwikkelen. 12 Het 15 gebruikelijk de volgende indeling van de kameralistische lee der openbare financlën te hanteren: ten earste de privaat-economle (met land-en bosbouw, technollagle en de leer van de hande1), ten tweede de bestuurseconomie, ten derde de leer der openbare financlën dat wil zeggen de kameraalwetenschappen in engere zlin, ten vierde de statlstiek, verder de bokkhouding en tenslotte die kamerad-praktijk. Wij zien overigens dat alle wakken die een economische faculteit vandag omvat in dit programia al voorkomen, de "stages", "practica" en "case studies" inbegrapen.

12 Jurgen Backhaus en Richard E. Wagner, "The Cameraltsts: A Public Cholce Perspective", Public Cholce, 53, 1987, blz, 3-20. 
Voor ans vooral van belang is uiteraard de leel der openbare financlën in engere $2 \mathrm{in}_{1}$ die vanaf $1727^{13}$ als academische discipline aan de universiteiten gedoceerd werd. Aan het eind van de achttiende eeuw (1798) bestonden er in het Duitse taalgebled al drieëntwintig leerstoelen, in Zweden zijn het in 1761-62 al vier, 14 in 0xford wardt de eerste leerstoel in de politieke economie in 1826 met Nassau Sentor bezet.

De grote inwloed van de kamerallisten wordt niet alleen door deze feiten duidelijk, maar zelfs door hun bijzondere naam onderstreept, 15 die betekent dat zij toegang hadden tot de raadskamer van hun regeryng. De naam maakt onmlskenbaar duidelijk tot wie de kameralisten zich met hun leer eigenlijk richtten: de op eigen werantwoordelijkheid beslissende en handelende regering. Het is in dit verband niet jutst on te stellen dat de kameralisten als kritiekloze dienaren van absolute vorsten beschouwd kunnen worden, die alleen trachtten de schatkamers van hun heren aan te wullen en verder geen theoretische inzichten en ambities in de economische wetenschap vertoonden. 16 Wel werden de regeringen toen valk -nfet altijd, er bestonden republieken-geleld door absalute vorsten. Maar de leer der kameralisten was julst tegen het absolutisme gericht en werd ultgewerkt als leer van de welwartsstaat. Het doel van het overheidsbeleid was de bevordering van de algemene welvaart.

Het is kenmerkend voor het kameralisme dat hun leer der openbare financtën zorgulidig is ingepast in een stelsel van economisch beleld dat alle beleldsinstrumenten gebrulkt die de overheid ter beschikking

13 De eerste leerstoel werd toen aan de universiteit van Halle ingesteld, gedurende hetzelffe jaar a volgde de tweede in Frankfurt $/ 0$.

14 Zie Dieter Schneider, Geschichte betriebswirtschaftschaftlicher Thearle, München: Oidenbourg, 1981, blz. 108.

15 Johann Heinrich Gottiob von Justi, Staatswithschaft oder Systematische Abhandlung aller ökonomischen und Cameralwissent= schaften. Lefpzig: Brettkopf, 1758, 1, 3: "ben Namen der Cameralwissenschaften aber leget man thnen deshalb bey, well die hohen Collegia, welche der Landesherr niedergesetzet hat, um die Geschäffte der Erhaltung, der Vermehrung und des Gebrauchs des Vermögens der Republik zu besorgen, gemeinfglich Carmern ader Cammercollegfa genennet werden."

16 Zie blfwaorbeeld J.J. Klant, Het ontstaan yan de staathutshoudkunde, Leiden: Stenfert Kroese, 1988, blz. 90. 
heeft. Als er érn economisch belludadoel walt te berelken is het wolgens de kaneralisten net voldoende voor de bieste economische matregel te kiezen. Het is tevens nodtg andere matregelen, bijvoorbeeld adrinlstratfeve matregelen, te bezlen die ook een belangrlyke invloed op de economile kunnen hetben. De comparatief beste matregel (valgens het Pareta matregel van de hele catalogus van beleldsmatregelen moet worden gevonden:

Vaak valt nlet te betwisten dat een bepalde matregel van de regering nuttig is en in het algemeen belang. Mar zodra men nagat hoe vele andere matregelen dle ook nutth zijn en verder gaan helemaal niet of nonchalant getroffen worden, dan vervalt elke anlelding voor lof die wij op het eerste oog dachten te hebten. 17

Deze zin kenmerkt de radfcale aanpak van de kameralisten. Johanm Heinrich Gottlob vom Justl (1702-1771) kan als éen van hun voornamste exponenten gelden. Hij wil het produktiepotentieel van een economie In zlifn geheel in dienst van de welvaartsstat stellen en het meest efflclënte gebrulk van de produktiemogelijkheden in de hulshoudingen, de landbouw, de industrie en nljwerheld en met name bij: de overheid berelken. De overheld wordt zelf als producent beschouwd en in dienst van de algemene welvaart gesteld. Het produktiepotentleel van de economie definieert Justi op zeer moderne wijze. Het onvat alle roerende en onroerende goederen die er in het land zijn ongeacht of $z$ ij zich in handen van particulleren of de owerheid bevinden. Daarbly komen nog alle vardigheden en alle kennls van diegenen die in de republifek leven, met andere woorden het beschlkbare menselljke kapitaal. Het optimale economische beleld besta.t daarin, dat het potentleell 20 flclënt mogel $1 j k$ wordt gebruikt. Er bestat een onverbrekelljke samenhang tussen het efficiënte gebrulk van het produktieve potentiel en het doel van de welvartsstaat. Hierult leldt Justl het fundamentele princlpe af dat het kamerallistische financlele beleld kenmerkt: die overheld streeft ernaar het produktieve potentleel (his noemt het vermogen) in de welvaretsstat te bevorderen en te vermeerderent. 
\$ 21 op den dur kan men het produktieve potentieel van een statu niet gebrulken zonder erop te letten dat het onderhowden wordt. Aangezten de beworderlng van de algemene welvatirt het doel vall de republitek is, moet de regering ernaar streven het vermogen en het produktlewe potentleel van de welvartsstat op alle manteren uit te breiden. Daarwit volgen wellswar meteen twee verschlllende beleidslijnen. De eerste is gericht op het onderhoud en de vermeerdering van het vermogen van de welvaartsstat en de twede streeft er nar dit vermogen zo efflciënt mogelljk aan te wenden. Daarom mot het financlële beleld van een overheld vanult deze twee gezichtspunten worden bekeken. De eerste onvat vooral de economie van het bestur en het belefd. Ze moet erop gerlcht 21 jn de economle van de welvartsstat in een goede stand te houden en uit te breiden. De tweede lijn onvat de kameralistiek in engere zin en beoogt het overheidsgedrag zo efflctënt mogelfjk op de algemene wellart af te stemen.

Vaak wordt het kameralysme (zoals ook het mercantllisme) varkeerd begrepen en wordt er verondersteld dat de kamerallsten er alleen maar op uft waren de schatkist te vullen. Maar Justi stelt al in alle duidelifkheid dat dit julst nitet de bedoeling is (\$23), er maet: precies voldoende geld (of goud) circuleren. Wel bestaat er een belangrijke ultzondering: het goud dat nodig is an in het geval van een oorlog gemunt te worden om de soldij te kunnen betalen. Maar gewoonlijk is het oogmerk van de stat erop gericht de juiste relatie tussen publieke infrastructurele voorzieningen enerzijds en particuliere Industrieün, nijverheid en handel anderzijas tot stand te brengen om de grens van de produktlemogelijkheden van het land te kunnen berefiken.

Otto Gerlach18 vat de hele leer van Just door een reeks van cytaten op een beknopte maniler siamen.

18 atto Gerlach, "Geschichte der Finanzwissenschaft unter besonderer Berucksichtigung der Lehre vom Verhältnts zwischen Volkswirtschaft, Staat und Finanzen". In: Die Entwickllung der deutschen Valkswirtschaftslehre in. neumzehnten Jahrhundert festschrlft Gustay Schmoller), II, Lelpzlg: Duncker \& Humblot, 1908, Hfdst. 38, biz. 6, 7. Gerlach elteert uit Justi's Staacsulpthschaft. 1758 (2). 
De statsinkomsten moeten op de minst schadellyke manter geind vorden en dan wel altyd nat verhouding wen het profljt van de burgers. De substantie vain het vermogen mag noolt aangetast worden en daaron mag ook alleen mar een deel van het proflyt van de burgers belast worden. Aan de andere kant mag de overheld ook niet te weinig urager: de owerheld moiet precies het juiste aandeel van het profist ontvangen, net te weinig en niet te veel. Het is zeker niet werstandtg en evenmin in het belang wan de weivart van de stat als de overheld over minder inkomsten en vermogens beschllt dan het produktleve potentleel van de staat toelaat zonder achteruft te gaan. Als de regering over gerlnge inkonsten beschikt kunmen wis verwachten dat vele matregelen achterwege moeten blijven die wel nuttig zijn (..). De rijkdom wan de republiek wordt nlet zo goed gebrulkt als het potentleel wan de staat toelat. Overlgens hebben te gerlnge belastingen vaak als gevolg dat het geld well bespaard wordt, mar nlet curculeert en dus net gewnvesteerd kan worden. Maar een wijze regering en haar schatkist. is net als een grote zee warin thet contante geld circuleert en door nuttige utgaven en ondermemingen naar alle delen van de landbouw terugwloett en aok de nljverheld tot rijke bloes lkan komen door het geld te laten circuleren:

Vanzelfsprekend hebben de belastingen bij zo"ln opzet een macroeconomische stuurfunctle. En toch wordt er meteen de warschuwing aan vastgeknoopt, die wij na de opkonst van functional fimance nlet altijd hebben onthouden, dat de belastimgen zo min mogelijk als last ervaren mogen worden. Dit principe vloeit direct voort wit het algemene doel van de welvartsstat. Toch $z$ ijn wij vandaag verrast hoe radical Just met dit principe ongat. Het wordt niet alleen op én belasting toegepast en de excess burden per belasting gemimimaliseerd. Het principe wordt comparatief gehandhafid en tegelljkertlja op alle bestaninde en mogelljke belastingen toegepast. De minst belastende vorm mot worden gevonden geri gehandhated.

Er is toch altijd cen bepalde belasting mér in strijd met de belangen wan hamdel en landbouw en de vrljheld van de burgers dan een andere; en als gevolg is de eerste vorm ook schadelljker woor het bellang van de regering en de algemene welwart dan de tweede. 19 
Justi doelt rechtstreeks op de samenting tussen belastingdruk en yrifheid van de burger 20 en benadrukt de samenhang lin zlin verwoording van de camon van belastingbeginselen die onvattender is dan de latere maar beter bekende van Adam Sint th $(1776)$. De nadruk op deze samenhang is meer dan een puur overblijfsel van de natuurrechtelijke constructie bij Christian Wolff. Justi weet een economische interpretatie an het principe te geven die tegen de achtergrond van de Europese eenwording (1992) als zeer modern overkont. De kameralistische staat bevindt zlch volgens Justi (en de andere kamerallisten) in een concurrentleposftle met andere staten. Dat houd in, dat de kameral1stische welvartsstat niet alleen voor zifn elgen burgers zo aantrekkelljk mogelljk moet zijn, on hun uittocht te woorkomen. De keerzijde wan dezelfde munt is dat de kameralistische stat ook voor burgers van andere staten, dle aan emigratie denken, zo aantrekkelijk mogelijk moet zijn on hen ertoe te bewegen met hun kennis en vaardigheden te immigreren. Dit is alleen mogelijk als de wrijheid van de burgers nifet aangetast wordt.

De matregelen ten anzlen van de bevolkingspolitiek zijn belangrijk voor de toestand wan de openbare financiën naarmate zij succesvol $21 \mathrm{Jn}$ of niet. Maar zij zijn zelf geen fiscaal-ecomomische maatregelen. Het zijn bestuursmatregelen en wij vinden ze bij Justi dan ook in zijn bestuurseconomie besproken. Boek 2 van deel I is aan het probleem van de toename van de bewolking gewijd. De bewoners van het land representeren het aanwezlge menselijke kapltaal en daarom zijn zij van enorm belang voor de economlsche ontwlkkeling. De bestuurseconomlsche matregelen zijn erop gericht het mensellijke kapitad aan te trekken en te laten groefen. Dat wraagt ten eerste (hoofdstuk 1) nawkeurige demografische en statistische kennis van amvang en toestand van de bewolking. In hoofdstuk 2 vinden wij de beginselen van het bellold besproken die er min of meer op neerkomen dat $z i j$ een vrlj en gezinsurtendel Ijlk matschappelijk kl inat moeten scheppen.

Wiets is zo nadellg voor de bevolking als een harde, onfechtvardige overheld de als een tiran het wolk onderdrukt lolz. 206). En het tweede fundamentele beginsell lutdt dat de regering het huwelijk moet steunen en waarderen. De overheid moet erop

Dit aspect wordt vandaag wooral door Buchanan en Hayek benadrukt. 
letten dat geen principes, meningen en houdingen in de stat

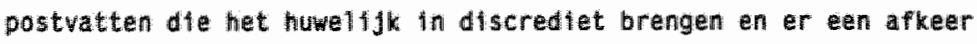
woor oproepen $($ b1z: 207$)$.

W1 gat verder met praktyche matregelen zoals het oprichten van een sparbank on arme meisjes in statit te stellen voor een butuschat te sparen. Hoofdstuk drie gad over matregelen om het land voor immigratle aantrekkellyk te maken en hoofdstuk vier over beleldsinltiat leven an te voorkomen dat de bevolking afneemt. Vooral de publleke gezondheldszorg is geschikt on de bevolking tegen ziekten te beschemen; ten twaede moet erop gelet worden dat de burgers geen aanlelding zien om het land te verlaten (belastingaruk). Tenslotte bespreekt Justi de noodzaak dat voldoende voedsel voor de eerste levenbehoefte tegen aanvaardbare prijzen ter beschikking van de burgers kont dat wil zeggen de toegang van de producenten tot de binnenllandse markten mag nlet belemerd worden.

Eén wan de belangriflkste ontwikkelingen op het gebted van de owerheidsfinancfën danken wij aan de kameralisten.21 De accljnsen werden door hen als een worm wan belasting onschreven die bijna niet als last ervaren wordt en toch een grote apbrengst levert. Teutophilus spreekt zelf van een "goudgroeve". Het belangrijkste verschil met andere wormen van belasting bestond erim dat de accijnsen bij een verstandige heffing geen effecten hebben die de produktle afremen. Vooral ondat

21 Hier is vooral het werk van Christian Teutophllus (Christian Tenzell, Entdeckte Gold-Grube in der Accise, Zerbst: Johamn Lüderwaldt, 1685 belangrijk. De volledige titel luldt: Entdeckte Gold-Grube in der Accise, Das ist, Kurzer ledoch Grüdilicher Berlcht von der Accise, Dass dleselbe nicht allein die allerrefcheste, sondern auch Pollteste, bliligste, und nutzlichste, ja etne gantz nötige collecte, umd also Zwiefacher Ehren werth sey. Darlnnen zur Genitge angeführet, Warumb die Accise in Deutschland durchgehends, und auff was Arth dieselbe Anfangs in einer Provinz oder Stadt, in deren Nachbarschafft die Accise micht, sondern die contribution in schwange, einzufüren In sonderheit aber behauptet wird, dass dieselbe das rechte fundament zu der neuesten polltilque und Commerclen-Beforderung llege, Wornebsit auch comparative Von der Contribution und Schatzung etwas beygefuget 15 t. Allen Obrigketten zu grossen Auffnehmen, und popultirung Ihres Landes, denen Stats- und Cammer-Bedfenten, zur Verminderung Ihrer Geld-Sorge, und denen unterthanen zur Erlelchterung Ihrer Last Volgestellet. Zle ook Gustav Schmoller, Dle Epochen der Preussischen Finanzpol1tik, Schmollers Jahrbuch, N.F. 1, 1877 en Foltz Karl Hann, Steuerpolitische Ideale Jena: Gustav Fischer, 1937, herdruk: Stuttgart, 1978, hoofdstuk 4 . 
zlj een (11chte) last op de consumptieve ultgaven leggen en darom het inkomen niet behoeft te worden geschat warop de belasting geheven moet worden. Een blykomend voordeel bestond erin dat de accijasen door de stenden miet goedgekeurd behoefden te worden. 20 werden de acciunsen een stap in de richting van democratisering (overigens waren anvanlikelijk de universftelten met hun leden wan de bier-accijns bevrijd, ean privillege warover vooral de studenten nawgezet wakten).

Samenvattend kunnen wij als conclustie stellen dat de kamerallsten al over een systematisch opgebouwde conomische theorle baschlkten warin de belangrijkste implicatles van de welwartsstat voor de openbare financiën verwerkt zijn. Dit geldt met name voor het beleld ten anzlen vain de belastingen en de soclale zorg. Bljzonder indrukwekkend is ook de nadruk die zly op de functies wan de huishoudingen alls kleinste producerende economische eenheden leggen, het op Ilquiditeft georlënteerde fiscale beleld en de moderne benadering van het menselijke kapltal als productiefactor. Hun financleel beleid is er al op gericht, het menselijke kapltaal zo produktief mogelijk te gebruiken en te onderhouden. Om dit doel te berelken is voor het soclale en financlële beleld een belangrijke funktie weggelegd.

\section{De fystocraten}

Vaak wordt het begin van de theorle der openbare financiên biJ de fysiocraten gezocht. De aanleiding dartoe is de impöt unique, de unleke belasting, die uit het kringloopschema (tableau économique) is afgeleid. De fyslocraten zijn inderdaad een belangrijke kracht bij de ontwikkeling van de economische theorlie geweest. Wij kunnem hen terecht als de eerste volwardige school in de geschiedenis van het ecomomische denken beschouwen, hoewel hun invloed maar korte tijd (ongeveer twee decennia) dururde. Hun elgenlijke bljdrage tot de lieer der openbare financiën, de unieke belasting of impôt unique, bleef mar een plan. De spectaculalre poging van de markgraaf van Baden, Carl Friedrlch, de unleke belasting in drie van zijn dorpen in te voeren en daarmee alle andere belastingen af te lossen mislukte. Het experiment moest 
Toch waren er een aantal pogingen de financfüle leer van de fystocraten in de praktijk toe te passen. Graag wh ik een voorbeeld noemen on te laten zien welke problemen zich daarbij voordeden. Eerder hebben wij al geconcludeerd dat het in de leer der openbare financtën erop aankomt, dat een theoretisch concept een praktische toepassing krijgt. Dit kan met behulp van een experiment gebeuren om te laten zlen, dat het theoretische inzicht in de praktijk deugt. 23: Tot onze verbazing vinden wij bif de fystocraten al een duldelljke timmuniseringsstrategie tegen een empirische toetsing. De methodologische samenhang is als volgt.

Er wordt vaak gesteld dat het tableau écanomique met het kringloopschema een analogie weergeeft van de mensellijke bloedcirculatie en dat dit de originele bijdrage van de arts François Quesnay (1694-1774) aan de economische wetenschap is. Françols Quesnay was tnderdaad arts. Op zijn posftie als lijfarts van Me de Pompadour berustte zijn politieke invloed. Het kringloopschema als analogle van de menselfjke bloedcirculatle werd overigens door Justi in de economische 1 ifteratur geintroduceerd.24 De analogie, waarvoor Quesnay koos en die hij ook aan de koning liet zien was juist niet de circulatie in een menselijk organisme, maar de mechanische kringloop van een kogel in een kogelklok als toepassing van het cartesiaanse mechantek op de economie. 25 Tot het beeld van een $k 10 k$ behoort ook de sleutel waarmee de klok opgewonden wordt. Deze slleutel was alleen aan de HERE GOD voorbehouden, ook de

22 Zie ook H.P. Liebel, "Enlightened Bureaucracy versus enlightened Despotysm in Baden, 1750-1792". In: Transactions of the American Philosophifal Soctety. N.S. 55, 1965, b1z. 40 .

23 James M. Buchanan, "Indivfdiual Choice in Vating and the Market". Journal of Polftical Economy, 62, 1953, blz. 343.

24 Zle Justi, 1758, blz. 259, biz, 263.

25 Lile Heinz Rieter, "Quesnays Tableau Economique als Uhren-Ana$\log 1 \mathrm{e}^{\prime \prime}$. Voordracht op de vergadering van de "dognenhystorlscher Ausschuss" van de "Vereln für Soctalpolltlk", Stuttgart, 13 maart 1986.

De fllustraties op bladzijden 20 en 21 geven ten eerste de officlële afbeelding van het Tablleau Economique en ten tweede een afbeelding van een typlsche kogelklok uit dezelfde tijd. Beide 11 lustraties zijn uft het manuscript van collega Rleter (Universitelt Hamburg) ontleend. 
koning mocht heim niet gebruken. wij mogen niet wergeten dat het fyslocratlsche kifingloopschema deel ultmakt wan een zeer speclfiake statsfllosofie.

Deze samemhang leldde tot opmerkelljke gevolgen toen de markgrafa carl Friedrich zich tot de Marquis de Mlrabeau wende om advies. Carl Friedrich vond het moellljk het fystocratische recept toe te passen ondat in zijn landen het frankische arfrecht gold en daardoor het land voortdurend gedeeid werd met als gevolg dat de landbouw (en daamee het "prodult net" achteruit ging. Carl Frledrich wroeg zich dus a of hij het erfrecht nlet moest wijzlgen, voordat hij het fysiocratlsme kon toepassen.

Carl Friedrich heeft hiemee een rechtseconomisch probleem juist opgevat en precles gesteld. Het probleem kon met een kameralistische benadering zonder meer worden opgelost zodat de welvart gemaximaliseerd kon worden. Het antwoord van de Marquis luldde nochtans: Markgraaf, $u$ hebt geen recht het door 600 gegeven erfrecht te wijzigen. Dat wll zeggen, de markgraaf mocht de sleutel nlet gebrulken.

Overheidsschuld, het publieke bankwezen en de ondernemende overheid

Indien wij proberen de twee klassleke werken in de leer der openbare financlën aan te wijzen die gedurende de vorlge eeuw de groatste invloed hebben gehad, dan kunnen wij nauwelljks aan David Ricardo's (1772-1823) Principles of Polltical Economy (1817) en Adolph Wagner's (1835-1917) Finainzwissenschaft $\left(1883^{3}\right)$ voorbljgaan. Het versch 11 tussen beide werken kan niet groter $z \mathbb{j n}$. Belde auteurs trachtten de leer der openbare financièn op een systematische manier in de algemene economische theorie van hun tijd in te voegen. Ricardo makt dit al duldelijk doar de opbouw wan zijn boek. Ongeveer de helft van de tweëndertig hoofdstukken is aan de ppenbare flnanclën gewlja. Dit gebeurt julst nitet op de bij de klassteke auteurs gebrulkelljke menfer. snth (1776) is daarvoor een goed Hoorbeeld. De leer der openbare financlën volgt bij hem in een apart boek na de ulteenzetting van de polltleke economie en wel min of meer zonder samenhang daarmee (boek V). Bij Ricardo staan belastingen en overheldsschuld in de analyse centraal. Wagner scheidt darentegen zorgvuldig de algemene economle van de leer der openbare financlën. Hij bouwt voort op de pollt teke 


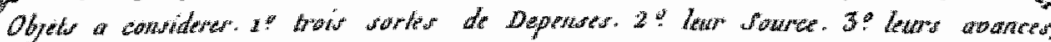

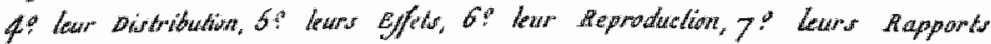

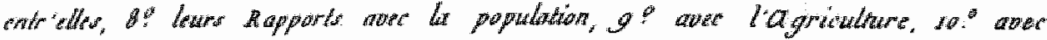

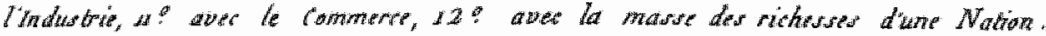

DERPASE

Productives

Rutitions its

l'agriculisire aco.

Avance annuelles

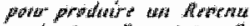

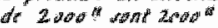

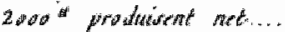

DEPENSES DU REVENU

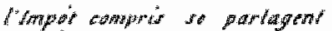

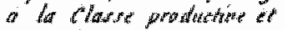

a la classe wirirle

Reveru

Antwet

$2400^{n}$

DEPENSES

Siériles

Alplations a

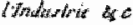

Avances annuelles pour list otumages des beperiser siterits wat soon

Otarages 20

Ptoductions

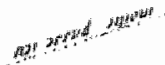

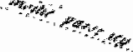

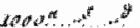

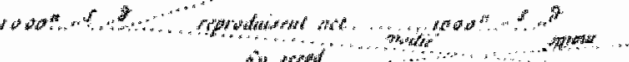

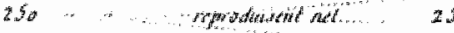

125

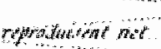

250

$\sin \theta$

25

aid . . .

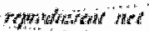

125

125

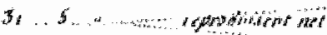

is

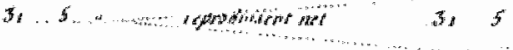

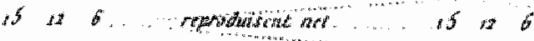

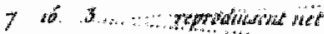

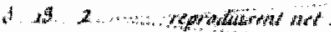

7.36

62, *t

3

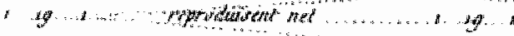

$3,18.2$

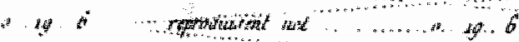

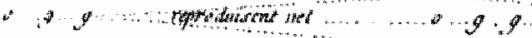

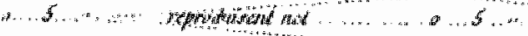

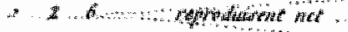

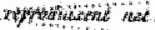

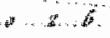

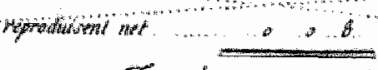

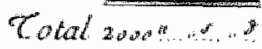

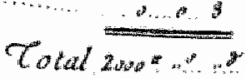

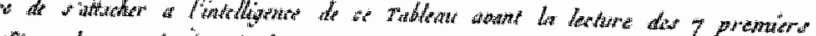

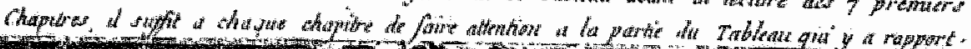


XTV

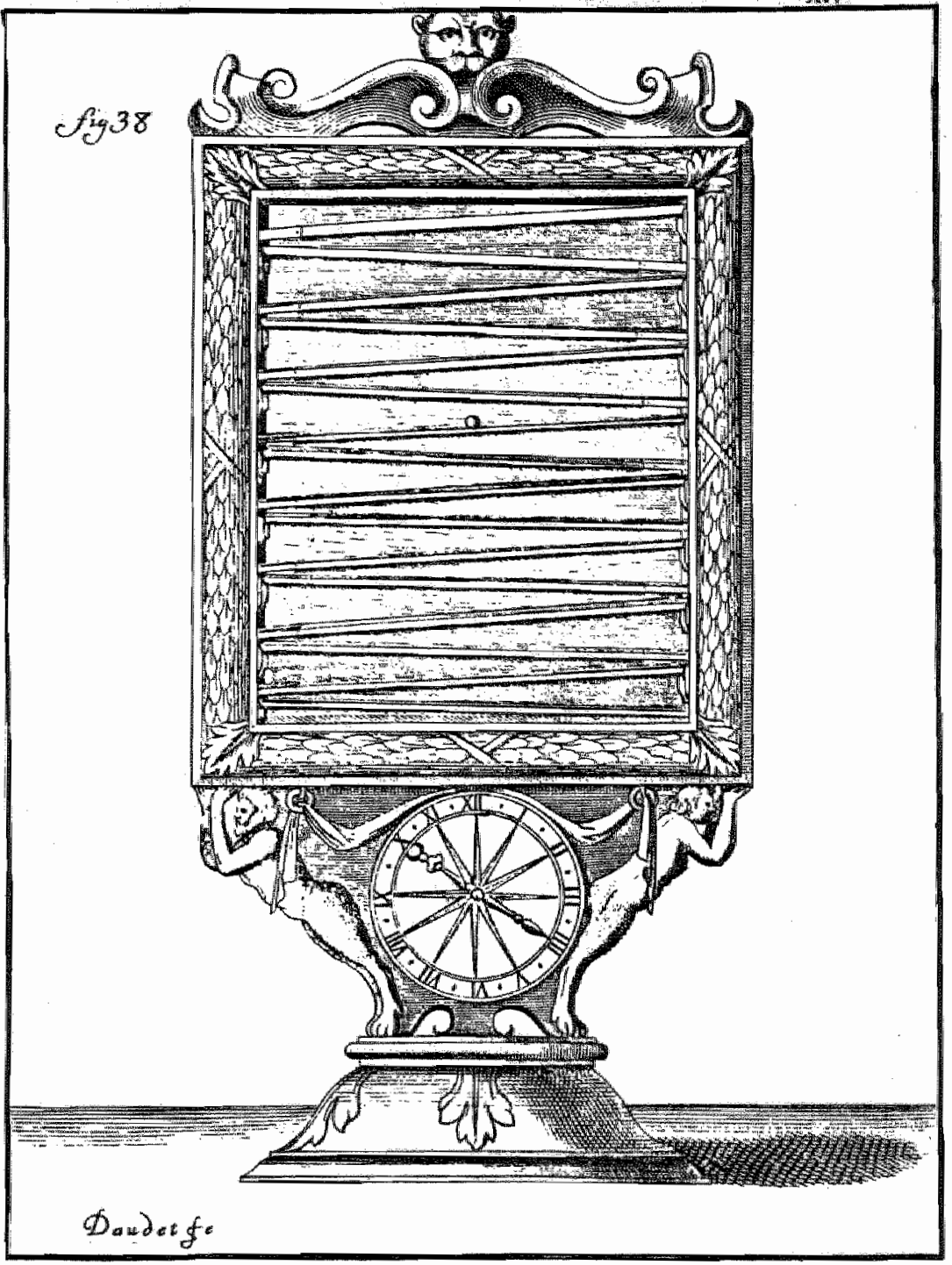


economie mar onderstreept de spectrleke Instituthonele en beleldsmatge wragstukken de voor de leer der openbare financten zo belangrijk en kennerkend zlJn. opmerkel lyk is ook de omvang. Magner's vier delen wan zlIn taer der openbare financiën (in vilf banden) zisn bijna. een lliustratie van zlJn wet wam de toenemende ultorelding wan het pverheldsgedrag ( 36$)$. Het eerste Iljulge deel begint met een inlelolng, zet de financlele ordening uteen en de financlè behoeften wan de overheld en gaat dan ommddellyk in op de privad-inkonsten van de stat, dat w11 zeggen de linkomsten uft ondernemerschap. Aan dit underwerp is het grootste gedeelte van de eerste band gewijd. De delen I1 tot IV gaan over de belastingen. Magmer's behandeling van de prlvat-inkomsten begint telkens met de beginselen van privatisering of matlonallsering van de speclfleke onderneming, bespreekt darina bljzonder problemen van de bedrijfstak en legt uiteindelijk een verband tussen de statsondernening en de financtele behoeften van de overheld. In dit verband komt ook het publleke bankwezen aan de orde en de administratte van de statsochuld.

Over dit onderwerp lezen 19 bij Ricarda26 het wolgende:

Wat $1 \mathrm{k}$ reeds heb gezegd, er moet nlet geconcludeerd warden dat $1 \mathrm{k}$ het systeem van lenen beschouw als het beste on de buftengewone kosten van de staat te bestrujden. Het is een systeem dat ons ertoe aanzet minder zuinlg te werk te gaan - ons te verbilinden voor de werkelijke situatie. Een land dat een grote schuld heeft gleaccumuleerd, wordt in een overwegend kunstmatige sttuatle geplaatst; en of schoon de hoeveelheld belastingen en de verhoogde prijs wan arbeid het niet noodzakellijk in een nadelige positie moet plaatsen ten aranzien van het buitenland, en lk geloof dat dat nlet het geval is, behalve de onvermljdbare noodzaak deze belastingen te betalen, zlly er toch andere problemen. De hoge belastungdruk lofdt eitoe dat het in het belang is van ledere belastingpllchtige on deze druk van zlyn elgen schouders af te wentelen op anderen. Deze druk bevoldert dat men zich verleld wolt om zich met zijn elgen kapltaal nar het bultenland te verplatsen, zodat men zal zifn gevrijward van deze lasten.

26 David Ricardo The Principles of Polltical Economy and Taxation, London: Dent, 1973, Hfdst. 17, b12. 163. 
Uiteindelijh wordt de druk ondeerstaanbar en wordt de naturill $1 \mathrm{jk}$ welgering van de mens on zifn geboorteplats en zilh eerste levensverbanden te verlaten, verdrongen. Een land dat in deze kunstmatige situatie terecht is gekomen moet zich hidrult bevrijden door de verkoop van alle delen van het publieke elgendon die voou de aflossing van de schuld nodig zijn.

Dit is het klassleke pleidool voor een oplossing van de problemathek van de staatsschuld door verkoop en prlwatisering vam vermogen in handen van de staat.

Het korte owerzicht over de opbouw van het werk van Wagner makt dujdelijk dat het klassieke advies niet overal gevolgd werd; misschlen amdat het niet gevolgd kon worden. Ricardo laat de processen wan beslufitvarming bif de overheld wolstrekt bulten beschouwing. Zoals in de klassleke angelsaksische traditie gebrulkelijk handhatt hij aen strikte schelding van markt en overheld. Zlin analyse beperkt zich uitsluitend tot de madelmatige benadering van een markteconomid en laat de overheld en har instituties bulten beschouwing die immers hun eigen wetten volgen. IK wil erop wijzen dat julst tussen de data van publicatle van deze twee belangrijke klassleke boeken de perlode van de opbouw van staatsbanken op het Europese continent ligt.

Een typlsch voorbeeld vormit de Preussische Seehandlungsglesellschaft (opgerfcht in 1772). Deze overheidsinstelling fungeerde niet alleen als handelsmatschappis. mar beheerde ook de opembare schuld en speelde verder een belangrijke rol als industrlële ontwikkelingsbank. Over hatar prestatie lezen wij in een vooraanstaande encyclopedie het volgende: 27 "Aangezlen de bank praktisch zonder elgen middelen startte en aangezten zij gedurende de latste 30 jaar een tekort op de staatsbegroting moest financieren, dat een streng bewakt staatsgehelm was, moet men toegewen dat har prestaties inderdaad witzonderlijk zijn. "Bovendien slagde de bank erin regelmatig ult har netto winst aanzinllyke bedragen an de

27 Zie W. Lexis, "Seehandiungsgesel1schaft" Handworterbuch der Socialwissenschaften * Vo1. 6, 1901, biz. 659-652. 
werheld ter beschiking te stellen.28

Over de verkouding tussen de prlvaat-likomsten en de rentelast van verschillende staten rond de eeuwlisseling informeert het tabel op bladzljde 19 van de Dultse tekst.

Een tweede samenhang tussen statsschuld en overheldsgedrag kan het verschil tussen tcardo"s en hagner"s: leer der openbare financten nog eens durdellik maken.

In het beroemde equivalentle-theorema postuleert kicardo dat een toename in de statsschuld meteen leidt tot een toename van de verwachte balastingschuld en tot een even grote toename van de particullere besparingen. 29 Wagner stelt uiteraard dat een toename in de verwachte belastingdruk als gevolg van een stijging van de statsschuld niet zonder meer kan worden verondersteld. De verwachtingen zijn afhankellijk van de manter warop de opbrengsten ult de lening worden besteed. Olt houdt in dat een goede (lucratieve) besteding fullst tot een verwachte dalling in de belastingdruk kan lelden.

Onze elgen berekeningen met hedendaagse Amerikaanse gegevens laten zten dat de emplrische: warheild ergens in het midden $11 \mathrm{gt}$. Een toename van het overheldsvermogen met eèn dollar gefinancierd uit lopende statsultgaven leidt tot en dalling van de private besparingen met zevenenv1jftig cent. 30 Darult kunnen will concluderen dat Amerikaanse burgers verwachten dat ongeveeir de helft van de overheidsinvesteringen produktlef $21 j \mathrm{~h}$, en de andere helft een consumptief karakter heeft. Alleen deze moeten door belastingen gefinancierd worden. Het slecht bestede deel van de staatsinvesteringen zal naar werwachting de

28 Z1e my Jn elgen bijdrage voor verdere detal1s. "Banking Institutions in Historical and Comparative Perspective: The Importance of the Entrepreneurlal state . In: Journal of Institutional and Theoretical Economles: Vol. 145.1, 1989, bilz: 210-214.

29 Ricardo lat wel een ultzondering toe die afhangt van de vorm warlin een belasting wordt geheven en dus voor het volgende nitet van belang is.

30 2le voor verdere detalls Jürgen Backhaus, Randall Holcombe en Asghar Zardkoohi, "Public Investments and its Effects on the Burden of the Public Debt" Southern Economic Journal, $54.1,1987$, b). 154-158, 
belastingoruk doen stijgen.

\section{Concluste}

Voor miln eigen vak trak ik daarutt de conclusie dat hat aan ons is om goede fiscale economen op te leiden, die het geld van de overheld goed en met profijt weten te besteden. Met als gevolg dat een stijgende staatsschuld bif het publiek de verwachting wekt dat de staatsleningen met profigt worden besteed en dat darom cen daling van de netto collectlewe lastendruk te verwachten valt.

\section{Een woord van dank}

Gaarme zou ik hierbil al diegenen willen bedanken die het mij feder op hun eigen wijze mogelijk makten deze rede vandaag te houden. Ik mocht hierbij veel steun en uriendschap ondervinden warvoor ik zeer dankbaar ben. In het bijzonder dank ik mijn vrouw die mij met zoveel begrip altigd terzijde stand. 